CORRECTION

\title{
Correction: Haemoglobin A1c and serum glucose levels and risk of gastric cancer: a systematic review and meta-analysis
}

Jiaojiao Zheng, Yunhe Gao, Shao-Hua Xie iD, Giola Santoni and Jesper Lagergren

(c) The Author(s) 2022

British Journal of Cancer (2022) 126:1109; https://doi.org/10.1038/s41416-022-01761-2

Correction to: British Journal of Cancer https://doi.org/10.1038/ s41416-021-01693-3, published online 13 January 2022

The article "Haemoglobin A1c and serum glucose levels and risk of gastric cancer: a systematic review and meta-analysis", written by Jiaojiao Zheng, Yunhe Gao, Shao-Hua Xie, Giola Santoni, Jesper Lagergren, was originally published electronically on the publisher's internet portal on 13 January 2022 without open access. With the author(s)' decision to opt for Open Choice the copyright of the article changed on 15 February 2022 to $\odot$ The Author(s) 2022 and the article is forthwith distributed under a Creative Commons Attribution 4.0 International License, which permits use, sharing, adaptation, distribution and reproduction in any medium or format, as long as you give appropriate credit to the original author(s) and the source, provide a link to the Creative Commons licence, and indicate if changes were made. The images or other third party material in this article are included in the article's Creative Commons licence, unless indicated otherwise in a credit line to the material. If material is not included in the article's Creative Commons licence and your intended use is not permitted by statutory regulation or exceeds the permitted use, you will need to obtain permission directly from the copyright holder. To view a copy of this licence, visit http://creativecommons.org/ licenses/by/4.0/.

Open access funding provided by Karolinska Institute.

\begin{abstract}
Open Access This article is licensed under a Creative Commons adaptation, distribution and reproduction in any medium or format, as long as you give appropriate credit to the original author(s) and the source, provide a link to the Creative Commons license, and indicate if changes were made. The images or other third party material in this article are included in the article's Creative Commons license, unless indicated otherwise in a credit line to the material. If material is not included in the article's Creative Commons license and your intended use is not permitted by statutory regulation or exceeds the permitted use, you will need to obtain permission directly from the copyright holder. To view a copy of this license, visit http://creativecommons. org/licenses/by/4.0/.
\end{abstract}

(c) The Author(s) 2022 